\title{
HAUSA IN FULA
}

\section{- A Morphological and Phonological Study of Hausa Loan-Words in Adamawa Fula ${ }^{1}$ -}

Ritsuko MIYAMOTO*

\section{ABSTRACT}

This paper investigates the way Fula, or Fulfulde, borrows vocabulary from Hausa, its most influential neighboring language in the eastern part of the areas where Fula is spoken. First, phonological features are described. Some consonants that do not exist in Fula are replaced by their closest correspondences, such as $z>j$, ts $>s$, ' $k>k$ etc. Second, morphological aspects of the borrowing are considered, especially referring to the Fula consonant alternation system. It is observed that the choice of which nominal class a Hausa loan should belong to is determined morphologically as well as semantically.

Another point is that only one kind of consonant-grade, namely the continuant grade, is allowed for suffixes of loan-words.

1. INTRODUCTION

2. METHODOLOGY

3. PHONOLOGY

3.1. Phonological Substitution

3.2. Consonant Alternation

4. MORPHOLOGY

4.1. Zero Suffix

4.2. Hausa + Suffix

4.3. Class Allocation

4.4. Suffixes

5. CONCLUSION

\section{INTRODUCTION}

Paul K. Eguchi reedited F. W. Taylor's A Fulani-English Dictionary (1932) into an English-Fula dictionary in 1986. Going through the dictionary, the author found that there were a fairly noticeable number of loan-words in Fula. This paper is the result of research on loans from Hausa, which is the nearest and most influential neighbor to Fula in the eastern Fulaphone areas. The data here are based primarily on entries in Eguchi's $A n$ English-Fulfulde Dictionary and Taylor's dictionary.

There are two possible ways or methods of a study of loan-words or foreign-original vocabulary. One is to see into the semantic field, that is, the classification of borrowed words according to which cultural categories they belong to. For example, if a religion was introduced by the lender, then the borrower is expected to have borrowed much religious vocabulary. This first approach is important for interlinguistic history. Greenberg (1947) and Skinner (1981) are studies of this kind about Arabic loans in Hausa ${ }^{2}$. The 
second is a morphological and phonological approach. What are characteristic features of borrowed words in terms of the grammatical system of the borrower language? This has, of course, importance for intra-linguistic study. This paper concentrates on the second method, aiming to see how Fula adopts foreign vocabulary into its internal grammatical, morphological and phonological systems.

Eguchi's dictionary contains 11,910 Fula entries, of which 1,670 , about $14 \%^{3}$ of total seem to have been borrowed from other languages. The largest number of them have come from Arabic, in other words, the most influential lender is Arabic, composing more than $50 \%$. Hausa comes next and the rest are Kanuri, Yoruba, English, French and so on. Those which seem to have come from Hausa count 524, 31.4\% of all the loans. It would be much higher in the areas such as Sokoto where the Hausa people are predominant and bilingualism in Fula and Hausa is fast progressing ${ }^{4}$.

\section{METHODOLOGY}

It is a very difficult task to identify particular words or forms as being borrowed from other languages. Especially, if the language concerned has been influenced by many other languages for a long time, then loans should have been well dissolved into the borrower's system. Furthermore, if the languages in contact are genetically related, then it is much harder to identify loan-words as such. The more closely related they are, the more difficulty arises. For example, it is much harder to identify loans from Wolof and Serer, the most closely related West-Atlantic languages to Fula, than from Hausa which belongs to a different language family.

Luckily for us linguists, the first contact of Fula and Hausa was not too long ago. According to the Kano Chronicle (in Palmer 1938, iii, pp. 111-12, cited in Hodgkin 1975, pp. 113-14), it was in the late fifteenth century that the Fulbe came to Hausaland. It seems, however, that the main penetration to the Adamawa area did not occur till the eighteenth century (Kirk-Greene, 1969, p. 127). F. W. Taylor, who had a good amount of knowledge of both Fula and Hausa, cited quite many etymologies of loans in his dictionary. Eguchi, moreover, added more information into the reedited dictionary. Therefore, it is entirely Taylor's and Eguchi's dictionaries that I rely on for etymological information.

However, it should be mentioned here that special attention has been paid in citing a word as borrowed from Hausa. It is quite important to decide which way the loan went. Did the word really come from Hausa to Fula or was it vice versa? In order to be certain, all the entries that seemed to have been loaned from Hausa were re-cheeked in Gaden's dictionary (Gaden, 1913-14) to see if the word concerned exists in western Fula dialects which have no Hausa influence. Hausa-English dictionaries were also referred to for the same purpose 5 .

In the course of the research, some points that are sociolinguistically interesting were found. While there is much vocabulary taken from Hausa to Fula, there are only a few words that went the other way. They are mostly kinship terminology and as expected, pastoral terms. Thus, $\mathrm{H}$ dattiijo < F ndottiijo 'middle-aged man of respectability'; $\mathrm{H}$ kaawu < F kaawu 'maternal uncle'; H baffa< F bappa 'paternal uncle'; $\mathrm{H}$ gwaggo <F goggo, gorgol 'paternal aunt'; $\mathrm{H}$ burugali< F burugal 'a stick used by milkmaids'; $\mathrm{H}$ nagge < F nagge 'a cow'; H jigaawalaa <F jigaawal 'vulture'. This shows Fula has had very little effect on Hausa, in other words, the Ful'be culture has had little influence on Hausa out- 
side of the family, domestic situation, or the nomadic life, even in the Adamawa area where the Fulbe are the most predominant population and their language, Fula is used as a lingua franca.

It is necessary to mention here how all the loans were determined to be borrowed from Hausa. In principle, 'the immediate lender' was counted. That is to say, if one word was borrowed from a language into Fula via another language, then the language it was borrowed directly from is counted as the immediate lender. For example, in the case of Fula soobaajo < Kanuri sava < Arabic saahib 'friend', Kanuri is considered as the immediate lender. Although the ultimate source is also cited when it is known, when it is not clear which language is the immediate source, it is the ultimate source that is counted. As far as loan-words in Fula are concerned, quite often the ultimate source is Arabic, besides those words directly borrowed from Arabic.

The criteria to decide the source are phonological ones. For instance, in Sudanese Fula, Arabic /h/ remains in loan-words when followed by a vowel. Thus, Ar jahannama > F jahannama 'hell'; Ar fiqhu > F figuhu 'Islamic jurisprudence' (Abu-Manga, 1986, p.48). Analogically, then, it is not likely that the Fula stem soobaa- was directly borrowed from Arabic saahib. Modification in vowels could be a clue, but in the case of Arabic loans in Fula, we do not find any systematic patterns (Abu-Manga, 1986, p.37) ${ }^{6}$.

Another point to be noted is that most vocabulary concerned here are nouns. It is simply because that we did not find many adjectives or verbs borrowed from Hausa in our sources. 7

\section{PHONOLOGY}

\subsection{Phonological Substitution}

For Fula speakers, Hausa is not too difficult in terms of pronunciation. It has almost the same kinds of vowels and a similar consonant system. The only major difference is that Hausa is a tone language and Fula is not. Consequently, tones in Hausa vocabulary lose their phonological value when taken into Fula. Most of the Hausa phonemes, therefore, are adopted as they are into Fula. Those which do not originally exist in Fula are substituted by their close correspondences. Let us see the following substitution patterns 8 :

(1) $\mathrm{z}>\mathrm{j}$

$\begin{array}{lll}\text { Hausa } & \text { Fula } & \\ \text { zangoo } & \text { jonngoore } & \text { 'camp' } \\ \text { zakka }(<\text { Arabic }) & \text { jakka } & \text { 'tithes' } \\ \text { zarto } & \text { jarto } & \text { 'file' } \\ \text { zaure } & \text { jauleeru } & \text { 'entrance hut' } \\ \text { zawwaati } & \text { jawaati } & \text { 'calico' } \\ \text { ziri } & \text { jiriiwol } & \text { 'bow-string' } \\ \text { zunguruu } & \text { junnguru } & \text { 'bottle-gourd' } \\ \text { kanazir } & \text { kananjur } & \text { 'kerosene' } \\ \text { janaa'izaa }(<A r .) & \text { janaa'uja } & \text { 'funeral' } \\ \text { kuza } & \text { kuja } & \text { 'tin' }\end{array}$

(2) $f>p$

$\underline{\text { Hausa }}>\quad \underline{\text { Fula }}$ 


$\begin{array}{ll}\text { mantanfas } & \text { mantampas } \\ \text { fale-fale } & \text { palepale } \\ \text { fam (<English) } & \text { pam } \\ \text { famfamii } & \text { pampamiiru } \\ \text { feetur (<Eng.) } & \text { peetur } \\ \text { furee } & \text { pure } \\ \text { fursuma (<Eng.) } & \text { pursuna } \\ \text { samfaraa } & \text { sampeera }\end{array}$

(3) $\mathrm{sh}>\mathrm{s}$

\begin{tabular}{|c|c|}
\hline Hausa $>$ & Fula \\
\hline$\overline{\text { shaa raa'baa }}$ & $\overline{\text { saaraa'b }}$ \\
\hline shigee & sigeewol \\
\hline shiruu & sirwa \\
\hline shiryaa & sirya \\
\hline shuu'dii & suu'da \\
\hline kilishii & kilisi \\
\hline kiliishii & kilisiire \\
\hline lawashii & lawasi \\
\hline
\end{tabular}

(4) ts > s

$\begin{array}{ll}\text { Hausa } & \text { Fula } \\ \text { kaatsi } & \text { kaasi } \\ \text { tsaamiyaa } & \text { saamiya } \\ \text { tsiree } & \text { sirel }\end{array}$

(5) ' $\mathrm{k}>\mathrm{k}$

$\begin{array}{ll}\text { Hausa } & \text { Fula } \\ \text { 'kabbaa } & \text { kabbau } \\ \text { 'kungurmii } & \text { karaw } \\ \text { 'kwaroo (< Kanuri) } & \text { kunngurumiijo } \\ \text { saa'ki } & \text { kooro } \\ \text { saaki }\end{array}$

(6) kwa > ko

$\begin{array}{ll}\text { Hausa } & \text { Fula } \\ \text { kwaagirii } & \text { koogiri } \\ \text { kwaakwaa } & \text { kooko } \\ \text { kwalabaa } & \text { kokoba } \\ \text { kwalooko } & \text { kolooko } \\ \text { kwaloo-kwaloo } & \text { kolo kolo } \\ \text { kwangwaina } & \text { konngayna } \\ \text { kwarkataa } & \text { korkota } \\ \text { kwaataa } & \text { koota }\end{array}$

But there are some examples which retain the original $k w$ :

$\begin{array}{ll}k w a ' d o o & k w a a^{\prime} d o \\ k w a k w a a & k w a a k w a \\ \text { kwaraa-kwaraa } & k w a r a a k w a r a a\end{array}$

'field gun'

'thin plate'

'pound'

'long trumpet'

'petrol'

'tobacco flower'

'prisoner'

'white leather skin'

'metal of sheath'

'cloth strip'

'silence'

'to prepare'

'blue'

'cooked meat'

'carpet'

'onion leaves'

'native cement'

'tamarind tree'

'bits of meat'

'syphilis'

'glass'

'expert thief'

'roan-colored cow'

'speckled bluish-black'

'cane'

'oil-palm'

'bottle'

'black dye for leather'

'small canoe'

'blue bead'

'jigger-insect'

'river side'

'embroidery'

'coconut palm'

'screen mat'

Gemination of nasals is quite often seen.

(7) $\mathrm{mb}>\mathrm{mmb}$ 


$\begin{array}{ll}\text { Hausa > } & \text { Fula } \\ \text { kimbau } & \text { kammbu } \\ \text { lambaa (< Eng.) } & \text { kimmba } \\ \text { sambeeruu } & \text { lammba } \\ \text { sammbeeru }\end{array}$

(8) nd > nnd

(9) $\mathrm{nj}>\mathrm{nnj}$

Hausa
kindai
munduwaa
tanduu

(10) $\mathrm{ng}>$ nng

$\frac{\text { Hausa }}{\text { man jaa }}>$
man jaa
wanzaamii $(<\mathrm{Ar}$.

\section{Fula \\ kinnde munnduwa tannduuru}

\section{Fula} mannjemannje mannja wannjamjo

\section{Fula}

jinngina jonngoore kunngurmiijo kuyanngaajo 'bangle of leather'

'guinea pepper'

'number, mark'

'a poisonous herb' 'basket work'

'large bracelets'

'a leather bottle'

'palm-oil nuts'

'palm-oil'

'barber' 'pledge'

'camp'

'expert thief'

'handmaid'

As far as vowels are concerned, no noticeable peculiarities were found in my research, except the case of (6) above where $k w a$ is changed to $k o$. Since Fula and Hausa have similar vowel systems, Hausa vowels are adopted in their original quality. However, it is quite often seen that the length of the vowels is modified: usually long vowels in the word-final position in Hausa are shortened in Fula when there is no suffix attached (viz. 4.1. Zero Suffix).

The sounds $/ \mathrm{z} /, / \mathrm{sh} /{ }^{9}, / \mathrm{ts} /, / \mathrm{k} /$ and $/ \mathrm{kw} /$ are not part of the Adamawa Fula phonology, therefore they are modified into their close phonemes. Although the /f/ exists in Fula, Hausa / $f$ / is modified to $/ \mathrm{p} /$ in loans. The quality of $/ \mathrm{f} /$, which is a bilabial fricative in Hausa, is ambiguous between [f] and [p]. It is even pronounced [h] in some dialects of Hausa (Ahmed and Daura, 1970, p. $75 \mathrm{ff}$.) This phenomenon $\mathrm{H} / \mathrm{f} />\mathrm{F} / \mathrm{p} /$ is because of the ambiguity of the Hausa phoneme, not the result of consonant alternation in Fula. There is some supporting evidence:

The case of Fula bappa $>$ Hausa baffa, the other direction of borrowing shows that /f/ $>$ $/ \mathrm{p} /$ did not originate in the Fula system. Furthermore, the class which pampamiiru belongs to requires /f/ for the initial consonant. Therefore, if consonant alternation were operating here, it would be famfamiiru. Thirdly, the cases of the /f/ in the mid-syllable position indicate that the alternation which applies only to initial consonants is not related (e.g. mantampas and sampeera).

Of course, many words from Hausa retain the original /f/ sound. Thus, F faadalfaadaaji $<\mathrm{H}$ faada 'court'; F faransaajo $<\mathrm{H}$ faransa 'Frenchman'; $\mathrm{F}$ fasa $<\mathrm{H}$ fashi 'to rob'; $\mathrm{F}$ Faasikiijolfaasiki' en $<\mathrm{H}$ faasikii 'evil minded person, hypocrite.'

The cases of (7), (8), (9) and (10) above should be considered as progressive assimilation: the syllable-final nasals affect their following consonants. It is interesting, though, that the affected consonants are all those which take part in consonant alternation. This might imply that the nasal grade of consonant alternants in the Fula morphology was 
originally phonologically determined.

\subsection{Consonant Alternation}

As for initial consonant alternation, only several loans were found to be alternated in our research:

(11)

Hausa
gabtaroo
fangalii
feluuwa
kasaa (verb)
saatii
gumaakaa
faashii
dooguwaa
gafakaa
shiruu

Fula
gaabtaro/waabtar'be
fanngaliire/panngaliije
felauwaare/pelwaaje
hasre/kase
saatiire/caatiijo
ngumaaku
paasitol
ndoogowa
ngafakka
cirwaaki

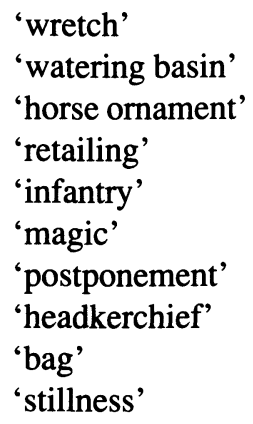

The initial consonant alternation system is the most important morpho-phonological operation in the Fula language. To outline the system, each noun takes one of the three grades (Stop, Continuant and Nasal) for its initial consonant according to the nominal class it belongs to. And roughly speaking, the allocation of which class a noun is included in is determined semantically, although it should be emphasized that there is no absolutely clear-cut rule for all the classes in contemporary Fula. For example, most of the nouns belonging to the $n d u$ class are circular and cylindrical objects, the $n g o l$ class are long thin things and so on, while those of the ngo and the $k a$ classes include various kinds of objects which cannot be generalized by their meanings.

In general, loans which came into Fula a fairly long time ago and have been well integrated into the system, can be expected to participate in the operation more often than recent ones. Therefore, the small number of Hausa words that undergo the alternation is reasonable, considering that Hausa loans are relatively recent as mentioned above.

We shall see how the class allocation is executed in the next chapter.

\section{MORPHOLOGY}

\subsection{Zero Suffix}

The most common morphological pattern of Hausa loans in Fula is that Hausa words are adopted in their original forms, and most of them are singular in number. Their plural forms are constructed by adding the most common plural suffixes $-j i$ or - je for non-human objects, -en for human beings with slight modifications of vowels by Fula phonological rules, e.g.

$$
\begin{aligned}
& \text { Hausa sg. = Fula sg. } \\
& \text { Hausa sg. }+-j i /-j e=\text { Fula pl. (non-human) } \\
& \text { Hausa sg. }+- \text { - }=\text { Fula pl. (human) }
\end{aligned}
$$

In other words, these nouns do not have any suffix of the class to which they are to be assigned on the basis of their agreement. Since the corresponding plural forms have the appropriate class suffix added to the stem, it is reasonable to regard the class they belong to as having 'zero suffix' in contrast with the overt suffixes of the other classes. e.g. 
(12)

Hausa
ajii
ashaanaa (< Yoruba)
buhuu
'dan alaaro
gooro
faada
kwalabaa
mangwaro
taagaa
turmii
yariima

Fula
aji/ajii-ji
asaana/asaanaa-ji
buhu/buhu-ji
'dan-alaarol-en
gooro/gooroo-je
faadalfaadaa-ji
koloba/kolobaa-ji
mangoro/-je
taaga/taagaa-ji
turmi/turmii-ji
yariimal-en

Fula

'class'

'match'

'sack'

'professional carrier'

'cola nuts'

'court, chief's residence'

'bottle'

'mango fruits'

'window'

'a bale of cloth'

'prince'

Most of the examples of (1) to (10) are also zero-suffix loans.

\subsection{Hausa + Suffix}

The zero-suffix nouns have other forms with suffixes at the same time, e.g.

(13) $\begin{aligned} & \text { Hausa } \\ & \text { ajii } \\ & \text { ashaanaa } \\ & \text { gooro } \\ & \text { kwalabaa } \\ & \text { mangwaro } \\ & \text { taagaa }\end{aligned}$

Fula
aji-walajii-ji
asaana-walasaanaa-ji
gooroo-re/gooroo-je
kolobaa-ru/kolobaa-ji
mangoroo-re/mangoroo-je
taaga-waltaagaa-ji

class sg./pl.

ngal'di

ngal'di

ndel'de

$n d u / ' d i$

ndel'de

ngal'di

They take appropriate suffixes according to the class. Then, how is it determined which word goes to which class? Let us see the allocation patterns.

\subsection{Class Allocation}

The class allocation is decided on two bases: semantic and morphological ones. As mentioned above, the Fula noun class system is basically semantically determined, therefore, if the meaning of a borrowed word is clearly understood by the Fula speakers, it would be allocated into the corresponding class by analogy, adding suitable suffixes. For example, personal nouns are so obvious to recognize as such that they are categorized easily into the human classes, namely, ol'be,en classes, e.g.

$\begin{array}{lll}\text { Hausa } & \text { Fula } & \\ \text { yariima } & \text { yariima/yariima-'en } & \text { 'prince' } \\ \text { magaajii } & \text { magaaji/magaaji-'en } & \text { 'tax collecter' } \\ \text { 'dan alaaro } & \text { 'dan-alaarol'dan-alaaro-'en } & \text { 'carrier' } \\ \text { 'koofaa } & \text { koofalkoofa-'en } & \text { 'slave on duty' } \\ \text { Tuuraawaa (pl.) } & \text { Tuurankee-jo/Tuurannko-'en } & \text { 'Europeans' } \\ \text { Hausa } & \text { Hausaa-jo/Hausa-'en } & \text { 'Hausa' }\end{array}$

On the other hand, if the meaning is not clear, or does not coincide with the Fula semantic system, then, it is all up to individual speakers or the word is thrown into the socalled 'neutral' classes, namely, -'dum class etc. The great majority of non-human loans go into the biggest, neutral class 'dum, such as:

$\begin{array}{lll}\begin{array}{l}\text { Hausa } \\ \text { 'asalii }(<\text { Ar.) }\end{array} & \frac{\text { Fula }}{\text { ali/'aslii-ji }} \\ \text { bookiti (<Eng.) } & \text { bookiti } & \text { 'origin' } \\ \text { 'bucket' }\end{array}$




$\begin{array}{lll}\text { lambuu } & \text { lammbu } & \text { 'irrigated farm' } \\ \text { fitinaa (<Ar.) } & \text { fitina } & \text { 'wrangling' } \\ \text { masiifaa (<Ar.) } & \text { masiifa } & \text { 'calamity, etc.' }\end{array}$

(Arnott, 1970, p. 128)

These show the appropriate agreement for the 'dum class, e.g. fitina 'dume? 'what wrangling?', masiifa 'du' um 'this clalamity', lammbu maw' dum 'a big irrigated farm', and so on.

Another common pattern is that the class is determined morphologically. That is, those Hausa nouns whose final syllables happen to be identical with Fula class suffixes are allocated in classes which agree with the suffixes. Their semantic field varies. It is a kind of metanalysis in that a part of a word is analyzed as a grammatical morpheme. Thus:

\begin{tabular}{|c|c|c|c|c|}
\hline Hausa & Fula & $\underline{\text { suffix }}$ & $\underline{\text { class }}$ & \\
\hline$\overline{\text { faada }}$ & $\overline{\text { faada }}$ & $-a$ & $\overline{k a}$ & 'court' \\
\hline buuke & buukalbuuke & $-a /-e$ & kal'de & 'chain helmet' \\
\hline daakaaree & daakaare & $-r e$ & nde & 'reprobate' \\
\hline kumaaree & kumaare & $-r e$ & nde & 'crested crane' \\
\hline
\end{tabular}

There are many more foreign words taken into Fula this way. In fact, the semantic variety of $\mathrm{ka}$-class nouns reflects the fact that most of them are of foreign origin.

Similar morphological treatment can be observed with Arabic loans in Swahili, such as kitabu/vitabu 'book', kibirtini/vibirtini 'matches' etc. These loans were allocated to class $k i / v i$, because the $k i$ syllables of the Arabic nouns were regarded as Swahili class prefixes (cf. Abu-Manga, 1986, pp.104-5).

\subsection{Suffixes}

It is well recognized that there are three different forms of allophones for the stem initial consonant alternation, e.g.

(17) alternation grades for stems

$\begin{array}{lllllllllllll}\text { Continuant: } & \text { r } & \text { w } & \text { w } & \text { y } & \text { y } & \text { f } & \text { s } & \text { h } & \text { b } & \text { d } & \text { j } & \text { g } \\ \text { Stop: } & \text { d } & \text { b } & \text { g } & \text { g } & \text { j } & \text { p } & \text { c/sh } & \text { k } & \text { b } & \text { d } & \text { j } & \text { g } \\ \text { Nasal: } & \text { nd } & \text { mb } & \text { ng } & \text { ng } & \text { nj } & \text { p } & \text { c/sh } & \text { k } & \text { mb } & \text { nd } & \text { nb } & \text { ng }\end{array}$

Likewise, there are four grades of consonant alternation for suffixes:

(18) alternation grades for suffixes

\begin{tabular}{|c|c|c|c|c|c|c|}
\hline Zero: & -el & $-\mathrm{ol}$ & -el & $-a$ & -0 & $-i$ \\
\hline Continuant : & -re & -wol & -yet & -ha & -'be & $-\mathrm{ji}$ \\
\hline Stop: & - de & - gol & -gel & $-k a$ & -'be & -'di \\
\hline Nasal: & -nde & -ngol & -ngel & $-k a$ & -'be & $-' \mathrm{di}$ \\
\hline
\end{tabular}

Checking suffix grades of Hausa loans (those having suffixes), it was found that almost all of them take the continuant grade for suffixes: -jo, -yel, -wa, -re, -ri, -wo, -wu, -wal, $-w o l,-h i$, and -ho, e.g.

\begin{tabular}{|c|c|c|c|}
\hline \multirow[t]{8}{*}{ (19) } & Hausa & Fula & \\
\hline & $\overline{\text { Batuuree }}$ & Batuuroe-jo & 'European' \\
\hline & agoogo & agoogo-yel & 'watch' \\
\hline & mootaa $(<\mathrm{E})$. & moota-wa & 'car' \\
\hline & bos $(<\mathrm{Y} .<\mathrm{E})$. & bos-wa & 'bus' \\
\hline & gaduu & gadu-wa & 'wild pig' \\
\hline & sulee $(<\mathrm{E}$.) & suley-re & 'shilling' \\
\hline & kипии & kunuu-ri & 'gruel made of flour' \\
\hline
\end{tabular}




$\begin{array}{lll}\text { garmaa } & \text { garma-wo } & \text { 'hoe, plough' } \\ \text { kabidoo } & \text { kabido-wu } & \text { 'raincoat' } \\ \text { jirgii } & \text { jirgi-wal } & \text { 'train, ship etc.' } \\ \text { suuraa }(<\mathrm{Ar} \text {. }) & \text { suura-wol } & \text { 'a chapter of the Koran' } \\ \text { dabinoo }(<\mathrm{Kn} .) & \text { dibinoo-hi } & \text { 'date-palm' } \\ \text { baabaa } & \text { baaba-ho } & \text { 'indigo' }\end{array}$

The reason may be phonological-since most of the Hausa words borrowed into Fula have vowels in the syllable-final position, the zero grade suffixes do not follow them. However, it does not explain why they do not take other grades. On the contrary, taking into consideration Arabic loans, the choice of grade for suffixes is not determined on a phonological basis. All the Arabic loans are attached by the continuant suffixes, no matter what the phonological constructions of original stems are (Abu-Manga, 1986, p. 81), e.g.

(20)

$\begin{array}{ll}\text { Arabic } & \text { Fula } \\ \text { muhandis } & \text { muhanndis-jo } \\ \text { fatiila } & \text { fatiila-yel } \\ \text { baas } & \text { baas-wa } \\ \text { banadoora } & \text { banadooraa-re } \\ \text { furum } & \text { furum-ra } \\ \text { sufra } & \text { sufra-wo } \\ \text { kanaba } & \text { kanaba-wal } \\ \text { jawaab } & \text { jawaab-wol } \\ \text { martaba } & \text { martaba-ho }\end{array}$

'engineer'
'flask'
'bus'
'tomato'
'bakery'
'metal tray'
'bench'
'letter'
'big mattress'

These examples show that the suffixes with continuants are combined with the stems that end in consonants as well as those ending in vowels.

This phenomenon, that is, loans with the continuant suffixes, is also reported to occur in Gombe dialect (Arnott, 1970, p. 91).

The fact that most loan words are associated with the continuant suffixes seems to indicate that the most basic, unmarked form of Fula nominal suffixes is in continuant grade. There is a discussion about what the basic, that is, the underlying, forms of consonants that undergo the alternation in Fula are. Almost all scholars who studied consonant alternation in Fula such as Klingenhebon (1963), Stennes (1967), Arnott (1970), and Anderson (1976) have claimed that continuant-grade form should be considered as lexical representation of items in alternating categories. The only writer who has challenged this assumption is Skousen (1972), who proposes the stop-grade form should be basic. The data in this paper seem to support the traditional hypothesis, at least for suffixes.

\section{CONCLUSION}

Fula has borrowed a large amount of Arabic vocabulary, sometimes straight from Arabic, usually through written sources, sometimes by way of other languages. In our research on Hausa loan-words, many were found to have been introduced from Arabic through Hausa. I limited this paper to concentrate on phonological and morphological aspects of Hausa loans, but a comparative study of how Arabic items were borrowed into Fula via different channels would be very interesting.

Furthermore, the relationship between the Hausa and the Fulbe are reflected in the loan-words. Despite the historical fact that the Hausa were subject to the Fulbe Islamic 
reformers, the Hausa are so powerful in contemporary economy-Hausa merchants are found in any small market all over Fulaphone areas east to Ghana-so is their language. Even in Adamawa where Fula is widely spoken as a second language by non-native Fula speakers, Hausa influence is immense. The precise description of their relationship awaits a study of cultural categories of loan-words, that is, a research of in what aspects of culture Fula has been more iufluenced by Hausa, which requires profound knowledge of history.

\section{NOTES}

1. This is a papin based on my preliminary report in the 17th issue of The Bulletin of HolySpirit Women's Junior College, pp. 101-6, 1989 and my oral presentation at the 26th conference of Nihon Afurika Gakkai (Japan Association for African Studies) at Keio University, Tokyo, June, 3rd, 1989. I owe much to Professor Eguchi for allowing me to use his own data. Any errors are entirely my own fault.

2. There is also a paper called "Two Essays on Arabic Loan Words in Hausa" by Goerner et al., 1966, ABU (Ahmadu Bello University), Nigeria.

3. Strictly speaking, the numbers here might not be very reliable because they are based on data collected in 1920's and 30's. Contemporary aspects of linguistic environments of the Adamawa area such as the linguistic policy of the post colonial time, may have changed the result (such as larger percentage of English and French loan-words). However, they are still useful as indices for comparison.

4. Refer to my article on Sokoto dialect of Fula for the linguistic situation in the Sokoto area, Miyamoto, 1989.

5. The most frequently referred Hausa-English dictionaries were Abraham's (Abraham, 1962) and Newman \& Newman's (Newman, P. and Newman, R. M., and CSNL, 1977). Abraham (1962) contains much vocabulary, but it is well known not to be reliable for final vowel length marking. Therefore, Newman et al., (1977) and Matsushita's Hausa-Japanese dictionary (Matsushita, S., 1988) were often referred to.

6. It might be different if we take into consideration Shuwa Arabic which is a dialect spoken in Borno next to Adamawa. The difference of loans according to the difference of source, that is, spoken or written, must be crucial especially for Arabic loans as Greenberg pointed out (Greenberg, 1947). See Kyari Tijani's description of the Shuwa Arabs in Adamu et al., 1986, pp. 62-73.

7. Some adjectives were found, such as $\mathrm{H}$ shuu'di > F shuu'di- 'blue' as in deptere shuu'dii$r e$ 'a blue book'; H algashii > F algas- 'green'.

8. As for orthography, the UNESCO method is adopted except for some letters that are difficult for printing. The implosives and ejectives are 'b, 'd, and ' $k$ instead of hooked letters, and the velar nasal $\mathrm{g}$ which shows up before $[\mathrm{g}]$ is shown as $\mathrm{n}(\mathrm{g})$. Tones in Hausa are not marked.

9. / $\mathrm{Sh} /$ is a phoneme in other dialects of Fula such as the Gombe diatect, while the Adamawa dialect has /c/ instead of /sh/. 


\section{REFERENCES}

Abraham, R. C., 1962. Dictionary of the Hausa Language, London, University of London Press.

Abu-Manga, Al-A., 1986. Fulfulde in the Sudan: Process of Adaptation to Arabic, Marburger Studien zur Afrika und Asienkunde, Serie A: Afrika Band 44, Berlin, Dietrich Reimer.

Adamu, M. and Kirk-Greene, A. H. M. (eds.), 1986. Pastoralists of the West African Savanna, International African Seminars New Series, No. 2, Manchester, Manchester University Press.

Ahmed, U. and Daura, B., 1970. An Introduction to Classical Hausa and the Major Dialects, Zaria, NNPC.

Ajayi, J. F. A. and Crowder, M., 1971 (third ed. 1985). History of West Africa, New York, Longman.

Anderson, S. R., 1971. The Organization of Phonology, New York, Academic Press. , 1976. "On the Description of Consonant Gradation in Fula," Studies in African Linguistics, Vol. 7, No. 1, 93-136.

Anttila, R., 1989. Historical and Comparative Linguistics, (second revised edition), Current Issues in Linguistic Theory, 6, Amsterdam/Philadelphia, John Benjamins.

Arnott, D. W., 1970. The Nominal and Verbal Systems of Fula, London, Oxford University Press.

1986. "Fula Language Studies: present position and future prospects," in Adamu et al.

Bargery, G. P., 1934. A Hausa-English Dictionary and English-Hausa Vocabulary, London, Oxford University Press.

East, R. M., 1967 (reprint). Stories of Old Adamawa, Lagos/London, West Africa Publishing.

Eguchi, P. K., 1986. An English-Fulfulde Dictionary, Tokyo, ILCAA (Institute for the Study of Languages and Cultures of Asia and Africa).

Furniss, G. and Jaggar, P. J. (eds.), 1988. Studies in Hausa-Language and Linguistics, London, KPI.

Gaden, H., 1913-14. Le poular, dialecte peul du Fouta Sénégalais, 2 vols., Paris, E. Leroux.

Goerner, M. and Salmon, Y. and Armitage, P., 1966. "Two Essays on Arabic Loan Words in Hausa", A. B. U. Department of Languages, Occasional Paper, No. 7, (unpublished).

Greenberg, J. H., 1947. “Arabic Loan-words in Hausa,” Word. 3, New York, 85-97.

- 1960. "Linguistic Evidence for the Influence of the Kanuri on the Hausa," Journal of African History, I, 2, 205-12.

Hair, P. E. H., 1967. The Early Study of Nigerian Languages, West African Language Monographs 7, Ibadan, Cambridge Univevsity Press.

Hiskett, M., 1965. "The Historical Background to the Naturalization of Arabic LoanWords in Hausa," African Language Studies, 6, 18-26. 
Hodgkin, T., 1960 (2nd ed. 1975). Nigerian Perspectives, a Historical Anthology, London, Oxford University Press.

Kirk-Greene, A. H. M., 1958 (reprint 1969). Adamawa Past and Present, London, Oxford University Press.

Klingenheben, A., 1963. Die Sprache der Ful, Hamburg, Augstin.

Matsushita, S., 1988. Hausago Shoojiten (a Hausa-Japanese dictionary), Tokyo, Daigakushorin.

McIntosh, M., 1984. Fulfulde Syntax and Verbal Morphology, Boston, KPI.

Miyamoto, R., 1989. "A Note on Some Features of the Sokoto Dialect of Fula," Journal of Asian and African Studies, No. 37, Tokyo, ILCAA (Institute for the Study of Languages and Cultures of Asia and Africa), 15-30.

Newman, P. and Newman, R. M. and CSNL, 1977. Modern Hauasa-English Dictionary, Ibadan, Oxford University Press.

Palmer, H. R., 1928. Sudanese Memoirs, Lagos, Vol. III, 92-132.

Pelletier, C. A. and Skinner, A. N., 1981. Adamawa Fulfulde, African Studies Program, University Wisconsin, Madison.

Sapir, J. D., 1971. "West Atlantic Languages: an Inventory of their Noun Class Systems and Consonant Alternations," Current Trends in Linguistics, 7, 45-112.

Skinner, A. N., 1981. "Loans in Hausa and Pre-Hausa, Some Etymologies, Berliner Afrikanische Vortrage, XXI, ed. by H. Jungraithmayr (Marburger Studien zur Afrikaund Asienkunde), Serie A, Band 28, Berlin, Dietrich Reimer, 167-202.

Skousen, R., 1972. "Consonant Alternations in Fula," Studies in African Linguistics 3, 7796.

Taylor, F. W., 1932. Fulani-English Dictionary, Oxford University Press. 